\title{
SOCIAL ASSIMILATION.
}

\author{
PART I. PRINCIPLES.
}

I. DEFINITION AND ORIGIN.

WRITERS on historical and social science are just beginning to turn their attention to the large subject of social assimilation. The impulse given to thought along this new line is mainly due to the influence of Ludwig Gumplowicz, who makes assimilation the most important social fact and considers it the cause of all advance in civilization. To him the struggle of races is the supreme law of social life, and the resulting "cross-fertilizations of culture" ${ }^{\prime}$ the cause of progress. ${ }^{2}$ This is the thesis of all his writings, and the masterly way in which he handles his theme has opened up a vast new field for the coming sociologist. Of hardly less importance in this regard is the work of Gustav Ratzenhofer, 3 and already through the combined efforts of these two the ground has been thoroughly cultivated and stands ready for planting. The Russian sociologist Novicow also recognizes the importance which the fact of assimilation is to take in all sociological theory, for he prophesies that in the future treatises on assimilation will form vast libraries, such as today are made by the treatises on strategy, tactics, or law. 4

That the subject has until recently received little attention is readily seen by a mere glance at the works of our leading

E. A. Ross, Social Control, p. 339. New York: The Macmillan Co., I901.

2 Gumplowicz, Der Rassenkampf, p. 254: "Durch die ganze Geschichte der Menschheit ein fortwährender Amalgamirungsprozess hindurchzieht, der, von den kleinsten primitiven syngenetischen Gruppen ausgehend, nach irgend einem uns unbekannten rassebildenden Gesetz die kleinen heterogenen Gruppen immer mehr zu grossen Gesammtheiten, zu Völkern, Nationen und Rassen zusammenschliesst und amalgamirt und sie immer gegen andere ebenso zusammengeschlossene und amalgamirte Völker, Nationen und Rassen in den Kampf und durch denselben zu immer neuen Herrschafts- und Culturgebieten führt, die wieder das Heterogene zusammenschmelzen und amalgamiren."

3 Die sociologische Erkenntnis. Leipzig: F. A. Brockhaus, 1898.

' 4 Novicow, Les Luttes entre Sociétés humaines, p. 128.

790 
sociologists and historians. The word itself rarely appears, and when the theme is touched upon no clearly defined, stable idea seems to exist, even in the mind of the author. Thus Giddings at one time identifies assimilation with "reciprocal accommodation." $x$ In another place he defines it as "the process of growing alike," 2 and once again he tells us it is the method by which foreigners in United States society become Americans. ${ }^{3}$ Nor are M. Novicow's ideas on the subject perfectly lucid, for he considers assimilation sometimes as a process, at other times as an art, and again as a result. He makes the term "denationalization" coextensive with our "assimilation," and says that the ensemble of measures which a government takes for inducing a population to abandon one type of culture for another is denationalization. Denationalization by the authority of the state carries with it a certain amount of coercion; it is always accompanied by a measure of violence. In the next sentence, however, we are told that the word "denationalization" may also be used for the non-coercive process by which one nationality is assimilated with another. M. Novicow further speaks of the art of assimilation, and he tells us that the result of the intellectual struggle between races living under the same government, whether free or forced, is in every case assimilation.4 Burgess also takes a narrow view of the subject, restricting the operation of assimilating forces to the present and considering assimilation a result of modern political union. He says: "In modern times the political union of different races under the leadership of the dominant race results in assimilation."5

From one point of view assimilation is a process with its active and passive elements; from another it is a result. In this discussion, however, assimilation is considered as a process due to prolonged contact. It may, perhaps, be defined as that process of adjustment or accommodation which occurs between the members of two different races, if their contact is prolonged and if the necessary psychic conditions are present. The result

${ }^{x}$ Giddings, Elements of Sociology, p. 49. $\quad=$ Tbid., p. 70. 3 Ibid., p. 49.

4 Novicow, Les Luttes entre Sociétés humaines, pp. I28, 152.

5 Burgess, Political Science and Comparative Constitutional Law, Vol. I, p. 2. 
is group-homogeneity to a greater or less degree. Figuratively speaking, it is the process by which the aggregation of peoples is changed from a mere mechanical mixture into a chemical compound.

Assimilation arises with the very beginnings of human association. Various modes of intercourse may have prevailed among primitive men. Their meetings may have been friendly, as is the case with the Eskimos today, or they may have been warlike. It is possible that the original state of human association was that of peace as it was that of independence. Quite likely is it, indeed, that this should have been the case, at a time when authority was not yet established, when customs were not yet formed, when association was yet so loose that even the bond of kinship was scarcely felt. Whatever may have been the organization of primitive society, whether promiscuity reigned and the mother-right, in consequence, had precedence over the father-right, as Bachofen, ${ }^{x}$ McLennan, ${ }^{2}$ and Morgan ${ }^{3}$ would have

'Bachofen, Das Mutterrecht, pp. xix, xx, 10. See McLennan, Studies in Ancient History, pp. 319-25, for a brief outline of Bachofen's views.

2McLennan, Studies in Ancient History, pp. 92-5.

3 Morgan, Ancient Society, chap. i. Bachofen from the study of myths, McLennan from the study of ceremonials, and Morgan from the study of American tribal institutions arrived at the conclusion that promiscuity was the original state of the human family. Posada, Théories modernes sur les Origines de la Famille, de la Société et de l'Etat, pp. 48-53. Spencer, in Principles of Sociology, Vol. I, p. 602, says: "We have thus to begin with a state in which the family, as we understand it, does not exist. In the loose groups of men first formed there is no established order of any kind: everything is indefinite and unsettled. As the relations of men to one another are undetermined, so are the relations of men to women. In either case there are no guides save the passions of the moment, checked only by fear of consequences." Also ibid., p. 610. LubBock, in the Origin of Civilization, p. 99, asserts that there was a period when kinship was determined by feminine filiation, but repudiates the idea of a period when feminine power was supreme. Giraud-Teulon, in his Origines du Mariage et de la Famille, pp. 240, 24I, admits that there was an epoch when the preservation of the species was the principal social and religious law. Thus he was led to assert the essential early predominance of woman and to say that "the great religious and political function of the queens of Egypt was maternity." The aim of DR. LothaR von DaRgun's book Mutterrecht und Vaterrecht is to show the distinction between relationship and power. The fact that relationship is traced through the mother in a certain group does not necessarily mean that feminine power is dominant in that group. 
us believe, or whether, as Sir Henry Maine ${ }^{x}$ and M. Fustel de Coulanges $^{2}$ strongly insist, the paternal element was paramount in descent and authority, in the first association of men, certain it is that contact of group with group was inevitable from the very beginning. At first the mere fact of contact spontaneously engendered assimilation, though, to be sure, it was feeble and unconscious. Contact of different peoples, whether caused by festivals or battles, led to complicated genetic relationships, and through heredity the individuals of different groups became more and more alike. Soon, too, assimilation was accelerated through the rite of adoption, which came into vogue early in the history of human association. Thus assimilation begins its work at the dawn of social life. This unconscious or spontaneous assimilation came into being simply through the working of the environment, through mere prolonged contact.

But since this study is concerned with assimilation as a social activity, consciously directed by the state - in a word, with purposive assimilation - it will deal only with societies that have produced a civilization. Consideration of spontaneous assimilation in groups that have achieved nothing, that have contributed in no way to the world's fund of established knowledge, will not be undertaken. How, now, did these civilizations arise? The proofs seem to be convincing enough to allow the answer: Through conquest, and the resulting amalgamation and assimilation of heterogeneous ethnic elements. Though Gumplowicz ${ }^{3}$ and Ratzenhofer ${ }^{4}$ are perhaps too sweeping in their statements that all race-contact was at first hostile and resulted in wars of extermination which were succeeded by wars of conquest, historical evidence supports the theory that civilized societies arose in consequence of conquest. In spite of the fact that Giddings designates Gumplowicz's Rassenkampf as his error $^{5}$ and says,

I MAINE, Ancient Law, p. II7; Early Law and Custom, chap. 7. "Maine relied on the fact of male jealousy made much of by Darwin to prove that the primitive family was under paternal power, and that promiscuous sexual relations could never have been general." (Giddings, Principles, p. 265.)

${ }^{2}$ Fustel de Coulanges, The Ancient City, chap. viii.

3 Der Rassenkampf, Part IV ; The Outlines of Sociology, Part III.

4 Die sociologische Erkenntnis, pp. 147-56. 5 Principles, p. 298. 
"Conquest has played so large a part in social evolution, .... . that certain sociologists [here reference is made in a footnote to Gumplowicz] have refused to admit that a community may become highly organized in any other way," " he acknowledges "that the great historical peoples were created by the superposition of races or sub-races." 2 To be sure, many factors coöperate in the formation of a complex social group. But does not Giddings grant that the truly complex social groups - those that have produced civilizations - have their origin in conquest, when he says:

Nevertheless . . . i it must be also admitted as one of the most certain facts of history that the most highly organized existing societies are composed in part of elements that have survived successive waves of conquest, in part of those that were once conquering forces but were afterwards subjugated, and in part of elements that won and maintained supremacy. In fact, for many generations the principle of ethnical subordination was seen in every part of the purposive organization. ${ }^{3}$

Perhaps not until types were somewhat set, custom somewhat fixed, authority somewhat defined, the tie of kinship somewhat realized, in other words, not until the group was firmly enough knit together to have attained some degree of self-consciousness, perhaps not until then did man invariably regard his fellow-man of another group as an enemy. Then began the struggle. Then Carlyle's question, "Can I kill thee, or canst thou kill me?" as between group and group, had to be answered.

At first extermination was the policy of the victorious host. Wars of extermination naturally left little impress on social development. But when the victors, instead of annihilating the weaker race and marching on to new conquests, spare them and settle down upon their land, the conditions for a step upward in human progress are laid. Political development resulting in the historical state begins when one group is able to make use of another in some other way than by eating them.

'Principles, p. $316 . \quad 2$ Ibid., p. 310.

3Ibid., p. 316. Woodrow Wilson's views seem to coincide with those of Gumplowicz: "Absolute isolation for any of these early groups would of course have meant stagnation; just as surely as contact with other groups meant war." (The State p. 24.) 
The conquerors enslave the subject men and marry the pick of the subject women. Thus the subjugated people forms a lower stratum in the new group. Slavery, the inevitable result of conquest, denotes progress, however, for it supersedes slaughter. The chronicles of all peoples show the sequence of slavery on war, says Spencer. The Egyptians had a slave class recruited in war, and Assyrian history, through its inscriptions, reveals a state of society similar to that existing in Egypt. The Hebrews were slave-owners, and they themselves became later enslaved by the Romans. Semi-barbarous society, as seen in existing tribes, repeats the story. "The Damaras are idle creatures. What is not done by the women is left to the slaves, who are either descendants of impoverished members of their own tribe . . . or captured bushmen." "The Biluchi (a tribe of Asia) do not themselves do the laborious work of cultivation, but impose it upon the Jutts, the ancient inhabitants whom they have subjugated. Says Tennent: 'Slavery in Ceylon was an attribute of race; and those condemned to it were doomed to toil from their birth." "I After the conquest the conquering minority perceives that without some degree of adjustment or accommodation it will be impossible for the victor and the vanquished to live side by side, and so a definition of position and rights follows, which, in the course of time, develops into institutions. Common life is now more advantageous than isolated life. Hence adjustment is made, the first result of which is some sort of political organization - the establishment of social order which is the necessary basis of social progress. Exploitation is the dominant note in the treatment of the conquered by the conquerors, and social inequality becomes the principle of organization in the new society. The conquered people are enslaved, or at least become a vast industrial mass which must work for the conquerors. In the course of time they are differentiated into classes of more or less social esteem. The conquerors reserve to themselves the right of control, and soon form the military, priestly, and political classes of the group. The castes of the East point to subject or conquering races: the

${ }^{2}$ Spencer, Principles of Sociology, Vol. III, 468, 469. 
agricultural classes of India are the Hindus who were conquered by the Mohammedans; these latter form the merchant and warrior classes. The Helots of Sparta were the original inhabitants of the Peloponnesus, while the warriors and kings were the Dorians who subdued them. With the settlement of the two races side by side begins, spontaneously at first, the process of assimilation; first agglomeration, and then assimilation. Mere agglomeration begets assimilation, for in these early ages of history, when society is just emerging from a tribal organization, all races are near enough alike to make the process of fusion comparatively easy. Then there is no body of tradition strong enough to produce a race-consciousness sufficiently intense to prevent assimilation. That the classes after the establishment of social order find themselves nearer each other than were the hostile races before the conquest is due to the workings of spontaneous assimilation. Thus, does not the historical, civilized state arise through conquest? Burgess, however, has quite a different view of the subject. The state is a late development of the nation, he asserts, which must pass through many preliminary stages in its development before it reaches the political organization or state. A nation he defines as "a population of an ethnic unity inhabiting a territory of a geographic unity." By ethnic unity he means a population having a common language and literature, common custom, and common consciousness of rights and wrongs. ${ }^{x}$ But, pray, how was this ethnic unity formed? This Burgess does not explain. Now, the establishment of such a unity was possible only through the assimilation which resulted from the conquest of one race by another, and this assimilation could be brought about only under political organization of some sort, or, in other words, the state. Social order was the necessary basis for social progress, and to social progress, caused largely by assimilation, the nation is due. ${ }^{2}$

Spontaneous assimilation begins with race-contact, but the moment the governing class realizes that homogeneity will be advantageous it proceeds to bring it about by every possible

I Burgess, Political Science and Comparative Constitutional Law, Vol. I, pp. I-3.

¿On "Die Entstehung des Staates" see Ratzenhofer, pp. 156-64. 
means, and thus assimilation is accelerated through deliberate, purposive action on the part of the state. In all early civilizations class, rather than national, homogeneity is the desideratum. As long as the majority of the people are dependent on the ruling class for life in this world and the priestly class for deliverance from the evils of the next, it is necessary that all within the governed class shall think alike. No original thought can be tolerated, and effort is made to mold all in a common form through the imposition of customary law.

Since stability is the essential feature in the early history of the state, since the establishment of political unity, military discipline, and security from outside attack is the aim, the effort of these days is, as Bagehot puts it, to cement a "cake of custom" $x$ over the group. The food to be eaten, the costumes to be worn, the ceremonies to be observed, the callings to be followed, are all prescribed. This rigid custom rule accomplishes beautifully the desired end, that all within a class shall think alike, feel alike, act alike, and is appropriate to the stage of nation-making, where class-homogeneity is essential. But, if carried beyond its proper stage, it stops the very process it started-progress; it destroys the very structure it helped to erect. Many groups enforced the custom rule so thoroughly that they were caught in the meshes of their own net and held fast. The object-lessons offered on this point by China, Spain, and Peru are familiar. Custom is thus all-binding in these early days and produces a formal unity within the class. Imitation of one class by another is not tolerated, however, and interclass assimilation does not occur. Custom is one of the greatest of all assimilating forces in ancient times, but while it cements firmly all within the class, it holds class apart from class.

Religion is the other chief agent made use of by civilizations, in the early stage of their development, for the purpose of assimilation. After the conquest the gods of the ruler become the national gods. "To have the same gods, to be watched, loved, and protected by the same deities, to be destined to join the

"Physics and Politics, pp. 27, 53. See especially chapters on "Nation Making," pp. $8 \mathrm{r}-\mathrm{I} 55$. 
same unseen company at death, these created fellowship" 1 in these early days. Thus in the first stages of assimilation, while differences are strongly accented, a degree of unity is attained, in spite of the rigid class system, through the identity of the attitude of all within the group toward the problem of existence and the future world. In all ancient civilizations the unknown plays so important a part that it is easier to establish "a set of fellowship feelings" ${ }_{2}$ on the subject of religion than on any other. Adjustment is therefore easiest, and consequently first to occur, on the subject of religion. The establishment of a subconscious mind, as Mr. Fairbairn calls it, ${ }^{3}$ is thus one of the early results of living together. The case of India offers a modern instance of this. There mixture of races has been greater than anywhere in Europe; the differences of blood, descent, character, and custom have been preserved and sharply emphasized by the inexorable caste system, and yet a wonderful identity of thought among all castes exists on the attitude toward life and death. This sub-conscious Hindu mind is utterly impregnable to western ideas, and the same thing may be said of the sub-conscious Chinese mind. By means, then, of religion a certain amount of unity is established throughout the group, irrespective of class distinctions, and a group-homogeneity is produced sufficient to hold the different elements together for long periods.

\section{THE PROCESS OF ASSIMILATION.}

From the foregoing it is quite evident that the conditions necessary to assimilation are both psychic and social. The psychic prerequisite is some degree of "consciousness of kind" 4 in the elements involved; the existence of a set of fellowship p. 437.

"E. A. Ross, "Social Control," American Journal of Sociology, Vol. II,

2 Ibid., p. 436.

3 A. M. FaIrbairn, "Race and Religion in India," Contemporary Review, August, 1899 .

4 Giddings, Principles, p. I7. According to Gumplowicz, "consciousness of kind" is "ein Gefühl der Einzelnen, vermöge dessen dieselben sich an die eine Menschengruppe enger angeschlossen und näher angezogen fühlen als an andere Menschengruppen." (Rassenkampf, p. 244.) 
feelings in the group. Without, therefore, a potential fellowship - a possibility of growing to see important things from the same viewpoint - a possibility of thought-sympathy on vital questions, assimilation cannot take place. The degree of assimilation will depend upon the latent powers in both groups and the assimilating forces to which they are subjected, which tend to reduce all to one type. ${ }^{x}$ Antipathy may be so great as to prevent all union. The Chinese is so utterly out of the sphere of thought of the western man that his non-assimilation to occidental culture seems well-nigh a foregone conclusion. The ideals of the Chinese are diametrically opposed to those of the western man; there are no common culture bonds between the two races; there is no possibility of agreement as to a viewpoint for matters essential to a common life. Hence, since all this precludes the formation of fellowship feelings, there can be no assimilation.

The social prerequisite is, of course, contact. This is brought about through intercourse, the means of which are both physical and psychic. Among the physical are the railroad, the steamboat, the telegraph, the newspaper, etc.; among the psychic are a common language, diffusion of the power to read, common tradition, common culture, etc. In ancient civilizations the difficulty of much contact between the members of the group was almost insuperable, owing not only to the force of custom which separated class from class, but also to the material and intellectual obstacles to intercourse, and the consequent hindrance to the spread of sympathy and the creation of fellowship feelings. Technical arts were still in their infancy, hence easy communication was not possible; nor were the psychic means of intercourse, a common language and power to read, widespread. Assimilation, therefore, did not progress rapidly in these days. Easy communication, made possible through inventions due to advance in mechanical arts, causes rapid diffusion of sentiment, and growth of fellowship feelings. Discussion through the school, the church, the club, the newspaper, accelerates the process of

"Mayo-Smith, "Assimilation of Nationalities in the United States," I, Political Science Quarterly, Vol. IX, p. 43I. 
assimilation. In general, the greater the number of points of contact, the more rapid will be the assimilation, and conversely. One of the reasons why the United States has such a great power of assimilation is that here both the physical and psychic means of intercourse are more highly developed than elsewhere. America has, perhaps, the most perfect system of communication in the world, a system which does much toward annihilating the barriers of space and time, and which is responsible for the simultaneous creation of sentiment and public opinion, throughout the length and breadth of our vast land. In Russia, on the contrary, on account of the poor means of travel and the censorship of the press which prohibits the publication of local news and the discussion of internal affairs of state, such a thing as common sentiment or public opinion does not exist. There is no knowledge on the part of the government at St. Petersburg of the interior condition of the empire. It is impossible to discover how reforms work in the provinces. The inevitable result of such a condition is to retard the process of assimilation. The unwieldy character of the Roman empire, too, was, no doubt, due largely to the lack of a perfected system of intercourse. Creation of a set of fellowship feelings throughout all parts of the empire, too, was, in consequence, impossible. Hence only a lax unity was realized. ${ }^{2}$ That intercourse accelerates assimilation is shown by the well-known fact that in high mountain regions and in islands, which present difficulties to communication, the population is always far behind that of the adjacent lowland or mainland in civilization. In the Caucasus region, which is called an ethnological museum, live tribes today which take us back to the time of Trajan. Bryce says: "It has also preserved ... .

$x$ "At the epoch of its greatest extension the Roman empire occupied five million square kilometers. Mechanical arts were not then developed enough to cause a vital circulation sufficiently intense throughout a territory so spread out. Maritime travel was moderately rapid . . . b but only during the warm season. In winter navigation ceased. Communication by land was much slower. After the great Roman roads were built and relays organized, the traveler could make one hundred Roman miles in a day. The most distant provinces probably could not be reached from Rome under three or four weeks. It took at least two months for the reaction in a distant province, toward any measure enacted at Rome, to become known in the capital city." (Novicow Les Luttes entre Sociétés humaines, p. 604.) 
fragments of the different peoples who, from time to time, have passed by it, or who have been driven by conquest into it from the lower country." ' The last persons to resist union with England were the Scotch Highlanders, and the mountain districts of our own country in east Tennessee and Georgia give instances of belated development. Also in islands, such as Corsica and Sardinia, traditions and ancient customs persist long after they have been given up in the mainland. In these places the blood feud or vendetta is still the popular method of meting out justice, and the ancient laws of hospitality are still in force.

The process of assimilation is of a psychological rather than of a biological nature, and refers to the growing alike in character, thoughts, and institutions, rather than to the blood-mingling brought about by intermarriage. The intellectual results of the process of assimilation are far more lasting than the physiological. Thus in France today, though nineteen-twentieths of the blood is that of the aboriginal races, the language is directly derived from that imposed by the Romans in their conquest of Gaul. ${ }^{2}$ Intermarriage, the inevitable result, to a greater or less extent, of race-contact, plays its part in the process of assimilation, but mere mixture of races will not cause assimilation. Moreover, assimilation is possible, partially at least, without intermarriage. Instances of this are furnished by the partial assimilation of the negro and the Indian of the United States. Thinkers are beginning to doubt the great importance once attributed to intermarriage as a factor in civilization. Says Mayo-Smith, "It is not in unity of blood, but in unity of institutions and social habits and ideals, that we are to seek that which we call nationality," 3 and nationality is the result of assimilation. Bryce, too, declares that intermixture of blood has not the effect once attributed to it. ${ }^{4}$ Waitz cites two

I Transcaucasia and Ararat, p. 51.

${ }^{2}$ TAYLOR, The Origin of the Aryans, p. 204.

3 "Assimilation of Nationalities in the United States," II, Political Science Quarterly, Vol. IX, p. 670.

4 "There are Europeans who hold - and in this physiologically minded age it is natural that men should hold - that the evolution of a distinctively American type of character and manner must be still distant, because the heterogeneous elements of 
opposed views as to the result of race-mixture. The one holds that it will ultimately cause degeneration, and the other that it alone is responsible for social progress. The first is the theory of Gobineau; the opposite, the view of Serres. Both views, however, are extreme, though there is more truth in the latter than in the former. ${ }^{x}$ But the belief that mere mixture of races will inevitably result in a superior people is untenable. Half-breeds, produced by the mixture of different races, have nowhere attained a high civilization. The Indian half-breed and the mulatto of the United States, as well as the Kaffir half-caste of south Africa and the Eurasian of India, uphold this statement. Mr. Galton, in his studies of heredity, published in Natural Inheritance, first demonstrated the tendency of the offspring of mixed races to revert to the parent types, and not to form middle types. ${ }^{2}$ Even where half-breed races have come into existence, says Taylor, there is a strong tendency to revert to one of the parent types. At the close of the last century the Griquas, half-breeds between the Dutch Boers and the Hottentots, were numerous at the Cape, but as early as 1825 they had practically reverted to the Hottentot type. ${ }^{3}$ Poesche's wide observation, extending over many years, led to the conclusion that without the infusion of fresh blood no race of mulattoes has maintained itself to the third generation. 4 In India there is no third generation of English blood. 5

the population .... must take a long time to become mixed and assimilated. This is a plausible view, yet I doubt whether differences of blood have the importance which it assumes. What strikes the traveler, and what the Americans themselves delight to point out to him, is the amazing solvent power which American institutions, habits, and ideas exercise upon newcomers of all races. The children of Irishmen, Germans, and Scandinavians are far more like native Americans than prevalent views of heredity would have led us to expect. . . . . I venture, however, to believe that the intellectual and moral atmosphere into which the settlers from Europe come has more power to assimilate men than their race qualities had power to change it; and that the future of America will be less affected by this influx of new blood than anyone who has not studied the American democracy of today can realize." (BRYCE, The American Commonwealth, Vol. II, p. 725.)

Anthropologie der Natur-Völker, Vol. I, pp. 422-4.

'Giddings, Principles, p. 233. 3 TAylor, The Origin of the Aryans, p. 199.

4 Poesche, Die Arier, p. Io; quoted in Taylor, p. 199.

5 TAYLOR, op. cit., p. 200. 
The belief that even a small infusion of foreign blood accomplishes good results is often instanced by the Norman Conquest, but the truth is that the assimilation produced by the Normans was of a mental rather than a physiological character. Very little effect could have been produced on the Anglo-Saxons as a whole through intermarriage, owing to the relatively small number of the Normans. The transformation of type into the English people was due to the effect of the superior continental civilization introduced by the Normans. Not all race-mixtures, moreover, have resulted in progress. Sicily, the meeting-ground of various races, has always been most unhappy. ${ }^{x}$ Giddings sums up the latest thought on the subject thus:

Mixed races, after natural selection has eliminated their weaklings, are taller, stronger, more prolific, and more adaptable than pure races. Anthropologists differ in regard to the limits within which cross-breeding is advantageous. Prichard's opinion (Natural History of Man, p. 18) that hybrid offspring are equally prolific whether their parent stocks are similar or most dissimilar races is still held by many investigators. The consensus of the best judgment on this subject, however, supports the conclusion of J. C. Nott, that two resembling races produce fertile offspring, but that when very unlike races are crossed the offspring show an inherent tendency to sterility when kept apart from parent stocks (Nott and Gliddon, Types of Mankind, p. 397). This is the belief of Vogt (Lectures on Man, p. 42I) and of Professor Broca (Phenomena of Hybridity in Genus Homo, p. 6o). On one point there is no dispute. Crossing creates physiological plasticity and variability. It is for this reason, indeed, that some hybrid races lack stability. Most of the ethnical elements that have mingled in civil societies have been sufficiently unlike to insure plasticity and individual vigor, and not so different as to impair the stability or the fertility of the resulting stock. ${ }^{2}$

It is readily seen that there are two elements concerned in the process of assimilation - the active and the passive - the assimilating people and those being assimilated. Consequently assimilation has a dual character-is more or less reciprocal in its action - a process of give and take to a greater or less degree. Attack is made by the assimilating people; response is given by those to be assimilated, and upon the character of this response depends the amount of interaction between the elements.

"Mayo-Smith, "Assimilation of Nationalities in the United States," I, Political Science Quarterly, Vol. IX, pp. 430, 43I.

${ }^{2}$ Principles, pp. 324, 325. 
Conquest changes not only the conquered, but also the conquerors [says Woodrow Wilson]. Insensibly, it may be, but deeply, they are affected by the character of the subdued or absorbed races. Norman does not merge with Saxon without getting Saxon blood into his own veins and Saxon thoughts into his head; neither had Saxon overcome Celt without being himself more or less taken captive by Celtic superstition. And these are but historical instances of what must have been more or less characteristic of similar events in "prehistoric" times. ${ }^{x}$

That interaction is bound to follow contact, be the intercourse never so little, is instanced by frontier life. When civilized man on the borders of civilization comes in contact with barbarous or semi-civilized races, there is modification on both sides. Though the civilized man is more able to resist than the rude man, he is influenced by his surroundings, and becomes callous and superstitious and lax in morals. But a glance at the Americans managing mines in Mexico substantiates this statement only too often and too well.

Whether the one or the other element involved shall predominate, and to what degree this predominance shall extend, or whether the process shall partake of the nature of an exchange, is determined largely by three factors: (I) the relative culture stage of the elements involved; (2) the relative mass of the two elements; and (3) the relative intensity of race-consciousness. ${ }^{2}$

When the planes of culture differ, the higher element tends to predominate over the lower. Professor Sayce lays down the general rule that when a small body of invaders bring with them a high civilization their language will prevail. Visigothic was soon extirpated in Spain; Dutch flourishes at the Cape. ${ }^{3}$ What is true of the language is more than likely to be the case with the rest of the culture of the invaders. When the dominant people are decidedly superior to the rest in civilization, they are able to impose their culture easily upon the conquered. Indeed, if the

I The State, pp. 26, 27.

${ }^{2}$ Gumplowicz declares that the result of race-collision is rigidly determined by law, the kind of people arising after the contact being wholly dependent upon the relative volume, weight, constitution, cohesion, and structure of the groups involved. (Soziologische Essays, p. I6.)

3 Principles of Comparative Philology, pp. 177, 178. 
inferior element is far enough below the superior in social development, it is possible that the conquering minority may be reduced to one man. Instance Bastian's testimony to the influence of one white man upon a whole savage community. The manner of life and personal habits of the tribe were greatly modified through his advent. ${ }^{x}$ Novicow asserts that if an Englishman establishes himself in Spain, Spanish society in his vicinity will ascend the ladder of progress, because the stranger brings an activity superior to that of the natives. ${ }^{2}$ The statement that the higher culture tends to prevail over the lower often holds good in cases where the higher culture is possessed by the conquered people. The Romans were partially Hellenized in the eastern part of their empire, and the triumphant Germans, in the barbarian conquest of Rome, were finally Romanized in what were once Roman provinces. Again, it is true that the nearer the planes of culture, the greater will be the interaction. When two races of about the same culture stage come in contact, characteristic traits of each will persist. There often results, therefore, instead of an imposition of the civilization of the conquerors upon the conquered, such a reciprocal action, such a modification of institutions and habits, in a word, such a fusion, that a new type, quite distinct from either of its component elements, arises. Perhaps one of the best examples of this reaction is seen in the Norman conquest of England and the resulting English type of culture. When the elements involved have approximately the same civilization, the language used after the conquest often shows how keen the struggle for predominance has been. If adjustment cannot be made immediately, a common meeting-ground is given through the use of a neutral tongue. Thus in Hungary, where there has been such a struggle of tongues, Latin was the language of administration up to 1849 . In the second place, the interaction between the elements

s "Dr. Petzoldt . . . . cites Bastian's testimony that even one short visit (to certain inner African tribes) from a white man is often enough to destroy the peculiarity of type. 'New tendencies are introduced and the stability is immediately diminished, though only to progress gradually to a newer higher form." (Williams, A Reviere of Evolutional Ethics, p. 430.)

'Les Luttes entre Sociétés humaines, p. 565. 
depends upon their relative mass. Though mass perhaps is not as important an influence as culture, it is without doubt a determining factor in the reaction. ${ }^{x}$ Other things being the same, the more equal the two elements in mass, the more reciprocal their action; hence the effect of assimilating forces varies inversely with the compactness of the passive element. It is greatest when the passive element consists of isolated individuals. All through ancient history both the attack and response in the assimilating process were mass-action. But in our own day and in our own land the process of assimilation of immigrants involves the action of a group upon an individual. Our vast body of immigrants comes, not as a horde, but as individuals, who scattering through American society are rapidly assimilated. The power of the assimilating element is overwhelming. There is little or no resistance on the part of the immigrant, and the process is accomplished almost without his knowledge. Here interaction is reduced to the minimum, yet it does exist. It is to be noticed especially in the effect of the German element upon our music and amusements. But that the resistance to assimilating forces is greater the more it is made en masse is shown by the persistence of alien customs in the Mennonite villages of Minnesota and the German settlements in Wisconsin.

The interaction between the elements depends, in the third place, upon the relative intensity of race-consciousness. The more intense its race-consciousness, the greater the resistance of the passive element, and possibly the greater its counter-influence; but this consciousness may be so intense as to prevent all assimilation. Greek civilization was not lost through the Roman conquest of Greece, because of the intense race-consciousness among the Greeks, which not only prevented surrender of their own peculiar culture, but was instrumental in causing its adoption by the victors. From the time of contact the Romans "played the Greek" in most matters of social life. In the eastern part of the empire Greek was the universal tongue. The

$x$ "Whenever two nations equally advanced in civilization are brought into close contact, the language of the most numerous will prevail." (SAYCE, Principles of Com parative Philology, p. I77.) 
Frankish assimilation of the Bavarians and Saxons offers a good illustration on this point. The Bavarians, a loosely united people, with little race-sentiment and tradition, yielded easily to the Franks, who soon imposed their whole system upon them. With the Saxons, however, a people of compact race-homogeneity, the case was quite different. By the end of the eighth century they were the only German people who still clung to their primitive religion and their social and political institutions. It took thirtythree years of hard fighting to reduce them to the rule of the Franks. Though Charlemagne forced the Christian religion and Roman law upon the Saxons, Saxon thought and custom in turn reacted upon the civilization of the conquering people. If raceconsciousness is intense enough to prevent change of attitude or adaptation to new conditions, assimilation cannot take place. Thus in India, English civilization has little or no effect on the Hindu, and in the United States the Chinese seems utterly impervious to American influence. In both these cases there is such a radical difference in tradition and history that fusion of ideas is practically impossible.

In concluding this chapter it may be well to sum up the laws of assimilation herein noted:

I. The greater the number of points of contact between the races, the more rapid will be the assimilation, and conversely.

2. When the planes of culture differ, the higher element tends to predominate over the lower, even though the higher culture is possessed by the conquered people.

3. The nearer the planes of culture, the greater will be the interaction.

4. Other things being the same, the more equal the two elements in mass, the more reciprocal will be their action; hence the effect of assimilating forces varies inversely with the compactness of the passive element.

5. The more intense its race-consciousness, the greater the resistance of the passive element, and possibly the greater its counter-influence; but this consciousness may be so intense as to prevent all assimilation. 


\section{THE PROCESS OF ASSIMILATION-CONTINUED.}

There are two strongly marked methods of assimilation : first, the coercive method, in which attack is made by force, and which marks the early stages of social growth; and second, the attractive method, in which attack is made by influence, and which occurs at a period of later social development. The action of the first is direct; of the second, indirect. The response in the first is caused through fear-a realization of differences; in the second it is caused by ambition - an intense realization of likenesses. The coercive method is suited to the stage of nation-forming ; the attractive, to the stage of nation-perfecting. The coercive method implies persecution; the attractive method, toleration. In the early days of civilization coercion was the method of appeal most potent with the great majority whose low intellectual development disposed them to yield readily through fear or awe. But as society progressed, and intelligence spread more and more throughout the group, this method became less and less effective, and resort must needs be had to other means. Hence the success of the coercive method through persecution depends largely upon the culture stage of the people upon whom the attack is made. This determines the character of their response, which is also influenced by their intensity of race-consciousness. The higher the culture, the more intense the race-consciousness of the passive element, the greater will be the difficulty of assimilation through this method.

A case in point is offered by the recent attempt of Germany to assimilate the Danes of North Schleswig. The Danes have a culture equal to that of the Germans, and cling tenaciously to their own language and traditions. They are the founders of the modern sciences of archæology and geology. In literature and art they have produced an Andersen and a Thorwaldsen; in agriculture and dairy farming Denmark leads the world. The fact that out of a population of two million in Denmark eighty thousand names appear on the subscription list of the Frem ("Forward"), a magazine devoted to popular science, shows how widely diffused culture is. North Schleswig fell into the hands of Prussia by the terms of the Treaty of Prague in I866, 
which closed the Austro-Prussian war. It had been ceded to Austria at the end of the war of Austria and Prussia against Denmark in 1864. Yet there was a clause in this same treaty which declared that if the inhabitants of the northern part of Schleswig should express by free vote their desire to be reunited to Denmark, their wish would be granted. In spite of a largely signed petition, however, Prussia, in accordance with her code of national ethics, refused to live up to her agreement, justify. ing her action by stating that the promise had been given, not to the people of Schleswig, but to Austria, who did not require its fulfillment. Yet the Danes of Schleswig acquiesced readily in the unjust demands of Germany, and submitted gracefully to their fate. A group of politicians and writers was formed among them to take upon themselves the task of creating sentiment for Germany. What race-antipathy there was soon died out in consequence, and the work of adjustment and assimilation was successfully begun. But the recent action of the German government by its coercive and prohibitive measures has stopped progress in this direction. All teaching in the school, with the exception of two hours' a week religious instruction, must now be carried on in German. Even private instruction in Danish is forbidden. An orator could not give a lecture in South Jutland in Danish, even if the theme were Goethe himself. Danish plays are not allowed on the stage, nor Danish songs in the concert hall. Even Danish colors on a lady's dress are not tolerated. If a Danish parent sympathizes too much with the cause of his fellow-countrymen, his child is forthwith taken in hand by the state and sent to German schools, where, in addition to the German language, he learns German ideals and hero-worship, for in the Volksschule emphasis is laid on the teaching of national history through biography. Though Danish sentiment grows stronger and resistance more determined as persecution increases, the German government still persists in its foolish course. The culture of the two nations is so similar that assimilation would be easy if the proper method were adopted. If the German government were to treat the Danes as the equals of the Germans, and show respect for their civilization and consideration 
for their customs, adaptation would naturally follow. It had begun before the coercive measures went into force. But now assimilation is at a standstill. ${ }^{x}$

The present policy of Russia in Finland in similar to that of Germany in Schleswig. Systematic oppression was begun about twelve years ago by Katkoff, the apostle of the doctrine of Russia for the Russians, and the champion of the suppression of the Poles and the Germans of the Baltic provinces. But it has become acute only within the last two years. Finland did not come into the Russian empire as a prize of conquest, but voluntarily, at the invitation of the Czar Alexander I., who, on becoming grand duke of Finland, took an oath to respect the rights of the Finns to self-government and to acknowledge the Finnish constitution. His successors have done likewise, and in spite of the fact that the present Czar, Nicholas II., took the oath to maintain the privileges of Finland as late as I896, decided encroachments have been made on the Finnish constitution, beginning under Alexander III., in I890. Then the postoffice and telegraph systems were reorganized and placed under Russian officials, and the Russian system of coinage was introduced. In 1898 Nicholas II. abolished the national militia of Finland, in which, according to the constitution, the military power of the country was vested, and introduced in its stead universal conscription. This was done about the time he issued his famous peace manifesto to the world. On February I 5, I 899, he issued a proclamation declaring it his sole right to interpret the constitutional laws of Finland. Thus he again violated the constitution by ignoring the share of the Finnish diet in this right. These acts caused great grief throughout Finland. Ladies put on black as a sign of public mourning, and a monster massmeeting was held at Helsingfors, the capital, where resolutions were adopted to draw up a petition of the entire nation asking for a reconsideration of the measures. But the Czar refused even to receive the petition. He also refused another one drawn up the following summer by the leading states of Europe and signed by $\mathrm{I}, 050$ scholars and artists, and which amounted really

'Georg Brandes, "Denmark and Germany," Contemporary Review, July, 1899. 
to a grand international protest. But Russia is pursuing her policy regardless of public opinion. The present governorgeneral, Bobrikoff, was appointed for the express purpose of Russifying Finland, and the new secretary of state for Finland, an office hitherto held by a native, is Privy Councilor von Plehwe, a member of Russian bureaucracy. The Czar has forbidden the formation of new societies for the advancement of culture in Finland; Bobrikoff has already suppressed one newspaper and has suspended the publication of two others for a month. One of these, the Nya Pressen, is the most prominent in Finland, and has stood for law and justice in the present struggle. The country is overrun with spies and gendarmes. The Finns are, without question, the most intelligent of the Czar's subjects. Out of a total population of two and one-half millions in 1890 there were only $2 \frac{1}{10}$ per cent. who could not read and write, whereas out of the hundred million of European Russians there were 80 per cent. From their history and traditions the Finns have learned such a respect for law and order and such self-control that their reaction to the oppression of Russia is slow. As yet no thought of rebellion has been entertained, and in spite of present conditions the University of Finland is the only one within the Czar's domains where work is carried on undisturbed. But national spirit is being strengthened by the oppression, and no headway is being made by Russia in her attempted violent Russification of the Finns. ${ }^{x}$

The resistance of the Armenians to Turkish oppression also offers a fine illustration of this point. Though the Armenians in Turkey are not formally united, yet they are a nation because of the feeling by which they are held together. Their raceconsciousness is so strong that they make no response to Turkey's attempt to assimilate them through persecution. They cultivate their old Armenian language and literature, because they are the badges of a past national life, and keep fresh in their minds the picture of a glorious past. Another instance of the failure

r See the following articles: EdWARD WestermarcK, "Finland and the Czar," Contemporary Review, May, 1899; "The Constitutional Conflict in Finland," North American Review, August, 1899; "The Downfall of Finland, An Object Lesson in Russian Aggression," Blackwood's Edinburgh Magazine, July, I899. 
of the coercive method is presented in Russia's persecution of the Jews. Before this cruel régime was started, the Jews were adopting Russian civilization, even to the extent of forgetting their synagogues. But the method of coercion in vogue for the past few years has utterly stopped assimilation. The Jews have too much tradition behind them, are a people of too high an intelligence, of too vigorous a race-consciousness, to be affected by this primitive method of assimilation. ${ }^{x}$

In one sense, however, the coercive method has sometimes been successful - so successful, indeed, that the government practicing it has overreached itself. Thus Spain through the Inquisition and through expulsion got so well rid of all original thinkers that the unity of opinion thus brought about has proved its doom.

The attractive method of assimilation works mainly through education and allows absolute toleration in regard to language, religion, and custom for individual use, requiring for national purposes one tongue. The best example of this is seen in the assimilation that is going on in the United States today, and which will be treated in detail later on. The two methods cannot be combined. The one arouses resistance to assimilating efforts, and solidifies the passive element. The other awakens

x"The Russians wish to identify their nationality with orthodoxy, not with Judaism. . . . Several years ago, under a regime of relative tolerance, the Jews began to assimilate quite rapidly and commenced to be actuated by patriotic sentiments. They began to love the country where destiny had cast them. Little by little they neglected the synagogue, and became indifferent to their own religion. But intolerance has changed all this. The Jews, deprived of a large number of civil and political rights, watched and persecuted on all sides, are recoiling within the bosom of their community. The synagogue has once more become dear to them, since it has been so persecuted. They are beginning again to frequent it. . . . Formerly numbers of Israelites became Christians. Now those who respect themselves do not change their faith. Conversions are very rare. Thus it is the Russian government itself which is placing obstacles in the way of Russification of its own subjects." (Novicow, Les Luttes entre Sociétés humaines, p. 566.) “ The Russian persecution .... is the direct act of a government deliberately, systematically, remorselessly seeking to reduce to utter misery about four and one-half millions of its own subjects. The laws of General Ignatieff in May, 1882, and the later and more atrocious measures that were taken at the instigation of M. Pobedonostseff, form a code of persecution which well deserves to rank with those that followed the religious wars of the sixteenth century." (LECKy, Democracy and Liberty, Vol. I, p. 559.) 
ambition, and breaks up the passive element and renders it plastic.

The dominant ideals in different societies determine the method that shall prevail and the resulting type of assimilation. The aristocratic ideal of loyalty to the king, unity of faith, and class authority results in the aristocratic type of assimilation, while the modern democratic ideal of universal brotherhood, equal opportunity, and realization of individuality gives rise to the democratic type. The aristocratic ideal is controlled by the distinctions of class and the power of position; the democratic ideal considers the people irrespective of classes, and values the man more than the position. In the aristocratic type the coercive method of persecution prevails; in the democratic type the attractive method of toleration reigns supreme. The main assimilating agent in the aristocratic type is religion. ${ }^{x}$ In societies practicing this type of assimilation it is all-essential that religious opinion shall be the same throughout the group. It must form the bond of union between classes which otherwise have no common meeting-ground save that of loyalty, which is itself more than half a matter of religion. To "fear God and serve the king" is the whole duty of man, or at least should be, in these groups. In the democratic type, on the contrary, religion is practically of no use as an assimilating influence. Here the chief agent is education. The aristocratic type of assimilation, which discourages interclass assimilation and promotes dissimilation through class antagonisms, will never produce national unity. Only the democratic type, which fosters interclass assimilation and annihilates class distinctions, can produce a nation in the true sense of the word. Examples of the aristocratic type of assimilation are furnished by all ancient states, and modern Russia, Germany, and Austria, etc. Concerning the policy pursued by the last nation, Bluntschli quotes the answer given by the emperor to the French ambassador when asked concerning the matter. Said Francis II.:

$x$ "The key to the whole composition of this early society was its religion. . . . . Religion was the one conclusive motive and sanction of all social order in that early time as it continued to be for many centuries afterward; and the heads of religion were, of course, the rulers of society." (Wilson, The State, p. 36.) 
My people are strangers one to another, and so it is best. They do not take the same malady at the same time. In France, when the fever comes it attacks you all the same day. I put the Hungarians in Italy and the Italians in Hungary. Each watches his neighbor. They do not understand each other and they detest each other. From their antipathy order is born, and from their reciprocal hatred, the general peace. ${ }^{x}$

An exam ple of the democratic type of assimilation is offered by the United States.

All states have given instances of partial assimilation; otherwise there would have been no social growth. But one cause of the repeated downfall of ancient societies is that there existed in them no true unity of the people; in fact, they contained no "people" in our modern sense. In a group where control is exercised by force, with the class system of rigid separation in operation, sympathy between the members of different classes is not encouraged. Unanimity of opinion on the most vital questions - those of rights and privileges - is, therefore, impossible. How could the master and slave, the lord and serf, think alike-be en rapport? The economic status of the different classes prevents the spread of like-mindedness; potential resemblance is limited by the economic system. Much dissimilation thus occurs in societies practicing the aristocratic type of assimilation, and they attain but partial or class assimilation. Such societies, however, desire but partial unity. Thus, Metternich did not care to Germanize the Slavs of Austria; he did not wish their intellectual horizon widened, for he thought he could use and abuse them more if they remained in ignorance. ${ }^{2}$ In such groups the imitative faculty is restricted, held in check. Imitation is allowed only within the class; it cannot extend beyond the lines laid down by law and custom. Assimilation is approximately complete or national only in the highest stage of social evolution, where class lines have about disappeared, and hence where there is practically no class opposition to hinder interclass association and sympathy - where there is no bar to the extension of consciousness of kind. Association is not perfect until it is pleasurable, sympathetic, and voluntary. When this

${ }^{x}$ Bluntschli, Allgemeine Staatslehre, p. i 10.

${ }^{2}$ Novicow, Les Luttes entre Sociétés humaines, pp. I34, 135. 
stage of intercourse has been reached, the desire to enjoy what others enjoy and the imitative tendency to act as others act accelerate the assimilative process, which at this period of social development attains such a degree of completeness that it may be called national. The United States approaches more nearly than any other country this stage of assimilation.

\section{THE PROCESS OF ASSIMILATION-CONCLUDED.}

Assimilating forces include those of the environment, both physical and social, and those implied by intermarriage. ${ }^{x}$ The main factors in the physical environment are climate and geographical features. These determine to a great extent the occupations, amusements, dress, and customs of peoples. The same physical environment for different races has the tendency to efface natural differences, through the identity of life, food, shelter, clothing, which it demands. If the new people yield readily to its influence and adopt the manner of life dictated by it, the physical environment has accomplished its work of preparation for the social environment which it in a measure determines. In the case of a conquering people settling on the land of the conquered the physical environment causes assimilation, to a certain point, of the conquerors to the conquered, and a necessary adaptation of social institutions to the new physical conditions, before the social environment of the conquerors can begin its action upon the subject race. The effect of the physical environment upon the intellect and the emotions of man, a point made much of by Buckle and his followers, is so indeterminate that it will not be here considered.

The social environment comprises all the influences brought to bear by the dominant people upon those to be assimilated. It is by no means coextensive with the physical or local environment. For instance, in the United States, broadly speaking, the social environment, through a system of easy communication, is made identical, or nearly so, for everyone. The United States does not present a series of strongly marked class environments,

'Mayo-Smith, "Assimilation of Nationalities in the United States," I, Political Science Quarterly, Vol. IX, p. 432. 
as do countries that practice the aristocratic type of assimilation, though here the marked distinction between city and country life still maintains. Bryce says of the United States: "The nation is not an aggregate of classes. They exist within it, but they do not make it up. You are not struck by their political significance as you would be in any European country. The people is one people, although it occupies a wider territory than any other nation, and is composed of elements from many quarters." $x$ Generally speaking, the greater the extent and identity of the social environment for all the members of any group, the more rapid will be the assimilation. In societies where the aristocratic type of assimilation prevails, isolation, both class and group, is the condition of the social environment. In the period of nationforming the all-important thing is to build up a social unity of heterogeneous elements. While the type is "setting," it is essential that there shall be no disturbance from the outside. Hence the practice of early governments in discouraging foreign intercourse and adopting a policy of strict isolation. Isolation of group from group is accompanied by isolation of class from class, only the minimum of group-unity - just enough to hold it together-being desired. In the society practicing the democratic type of assimilation, on the contrary, free intercourse is the condition of the social environment. Easy means of communication and expression make it possible to infect a great mass of people with the same ideas. Thus public opinion vibrates from end to end of the land, and touches even the most ignorant. This is true in the United States, where "the organs through which opinion finds expression" are "more adequate as well as more abundant... than they are in any other country." 2

I The American Commonwealth, Vol. II, p. 296.

2 "In the United States public opinion is the opinion of the whole nation, with little distinction of social classes. . . . . Nor is there any one class or set of men, or any one 'social layer,' which more than another originates ideas and builds up political doctrine for the mass. The opinion of the nation is the resultant of the views, not of a number of classes, but of a multitude of individuals, diverse no doubt from one another, but for the purposes of politics far less diverse than if they were members of groups defined by social rank or by property." (BRyCE, The American Commonwealth, Vol. II, p. 260; also ibid., p. 272.) 
The assimilating agents of the aristocratic type of society are religion, custom, and ceremonial, while the chief influences making for assimilation in the democratic type are community of interest, brought about by free education, free suffrage, and free commercial intercourse; public opinion created through the school, the club, the political meeting, the theater, the newspaper; reigning standards and ideals; and basic ideas, the chief among which are equal opportunity, natural rights, dignity of human nature, etc. Contrasting the assimilating agents of the two types, and summing up in a word the difference between them, we might say the all-important power in the aristocratic type is religion, while in the democratic type it is education.

Even a slight response on the part of the passive elements starts assimilation, and the inevitable result of continued contact is intermarriage, which does much to accelerate the process. Intermarriage affects the second generation. A population having the blood of both elements in its veins is more readily influenced by the dominant element than before the mixture of race occurred.

The psychic forces causing the response of the passive element to the environment are: (I) power of appreciation-not apathy; (2) ambition-desire to imitate; and (3) power to imitate. It is evident that there must be some appreciation of the new life with which the passive element has come into contact, or it will have no effect. Because the Italian immigrants who have been thronging to our shores within the last few years are utterly incapable of appreciating the superior conditions of American life, they are little influenced by their new surroundings. In the aristocratic type the brutishness of the classes chained to toil and the absence of liberty to imitate retard assimilation. In the democratic type the unrestricted play allowed such powerful human instincts as ambition and imitation is responsible for much of the success of the assimilating process.

From the foregoing it is easily seen that the proximate cause of assimilation, both spontaneous and purposive, is imitation. In a general way, it has long been conceded that imitation 
is a universally potent force in human society, but not until quite recently has scientific study been made of imitation as a social factor. The name of M. Gabriel Tarde $^{x}$ is most prominently connected with this investigation, yet thirty years ago Walter Bagehot appeared as a forerunner of Tarde. He saw clearly the importance of imitation as a socializing power, and expressed his view in Physics and Politics. Through the workings of the imitative faculty he accounts for the evolution of national character :

At first a sort of "chance predominance" made a model, and then invincible attraction, the necessity which rules all but the strongest men to imitate what is before their eyes, and to be what they are expected to be, molded men by that model. This is, I think, the very process by which new national characters are being made in our own time. In America and in Australia a new modification of what we call Anglo-Saxonism is growing. A sort of type of character arose from the difficulties of colonial life - the difficulty of struggling with the wilderness; and this type has given its shape to the mass of characters because the mass of characters have unconsciously imitated it. . . . I believe this unconscious imitation to be the principal force in the making of national characters. ${ }^{2}$

$\mathrm{He}$ forcibly states his conviction that imitation is the main factor in social life in the following words :

I want to bring home to others what every new observation of society brings more and more freshly to myself - that this unconscious imitation and encouragement of appreciated character, and this equally unconscious shrinking from and persecution of disliked character, is the main force which molds and fashions men in society as we now see it. Soon I shall try to show that the more acknowledged causes, such as change of climate, alteration of political institutions, progress of science, act principally through this cause; that they change the object of imitation and the object of avoidance, and so work their effect. ${ }^{3}$

Sir Henry Maine also recognized the importance of the factor of imitation in the early associations of mankind :

Nothing seems to me to have more affected primitive society, and yet to have been more neglected by those who have theorized on it, than the imitative faculty, which man has always possessed and which Sir Alfred Lyall has witnessed in actual employment by barbarous men. On superficial consideration, we are apt to think that man's mimetic faculty confines itself to matters of taste

'Les Lois de l'Imitation; La Logique sociale; Les Transformations du Pouvoir.

2 Physics and Politics, pp. 36, 37. 3 3 Ibid., p. 97. 
and personal habit. But, in truth, there is no successful or conspicuous or simply fashionable model which men in the various stages of their progress will not endeavor to imitate. The habit of political imitation, which has always been strong, still survives. . . . . The agency by which the imitation is carried out is Fiction, sometimes of the most audacious kind, and through it an old order is constantly giving place to a new. . . . . If an institution is once successful, it extends itself through the imitative faculty which is stronger in barbarous than in civilized man. ${ }^{\mathrm{x}}$

Still, to M. Tarde belongs the honor of having made such a careful and original exposition of the subject of imitation that the attention of sociologists has since been critically drawn to the matter. Tarde has identified his name with the word "imitation" as completely as Darwin has his with the word "evolution." In societies practicing the coercive method of assimilation imitation is not allowed full sway. It is limited by class lines, is restricted to what Tarde calls "custom imitation," 2 or imitation of ancestors. But where the attractive method reigns, imitation is unrestrained and results in national assimilation. Here custom imitation yields greatly to "mode imitation," or imitation of things new.

The task of denationalization or assimilation is, according to M. Novicow, to impose all the psychical manifestations elaborated by one society -its language, religion, philosophy, science, literature, arts, law, manners, and customs-upon another society. ${ }^{3}$ But he further intimates that, after nationality has thus been acquired, there remains for assimilation a still higher duty, namely, the establishment of great international federations, or "groups of civilization," as he calls them.4 These groups will be stable and permanent, for they will be founded on an intellectual, rather than a material, basis. This great desideratum will be brought about by the assimilation of ideas, which is made possible through progress in science and invention. Signs that such a movement is at hand are not wanting. Indeed, over a hundred years ago Rousseau declared that there were no longer Frenchmen, Spaniards, Germans, or even Englishmen-only

I Early Law and Custom, pp. 284, 285.

${ }^{2}$ Les Lois de l'Imitation, chap. vii.

${ }^{3}$ Les Luttes entre Societés humaines, pp. 128, 129. $\quad{ }^{4}$ Ibid., pp. 575-98. 
Europeans. They had the same tastes, the same passions, the same manners; and how much more is this true today, exclaims M. Novicow. Every day the economic, literary, scientific, and artistic interests of all Europe are becoming more and more intermingled:

Every year, be it a good year or a bad year, there are a dozen international congresses where ideas are exchanged, discussed, and brought to light ; where there is created a sort of union between the members of the same association and of the same profession, whatever their nationality. An invention made at Rome becomes immediately known and tried in New York and in Moscow. A scientific discovery does not remain localized in a city or in a country; it soon becomes the possession of the entire world. Humanity forms at present a great unit, having community of life, ideas, and manners. ... The large cities are already similar; . . . . the fashions are the same; the same operas are given on the stage; the cuisine is uniform; the system of tramways, omnibuses, hotels, post, telegraph, and railroads varies but little. In brief, one enjoys the same life in New York, London, Paris, Rome, Berlin, Vienna, Madrid, and St. Petersburg. ${ }^{x}$

With the progress of science people all over the civilized world come to think more and more alike, become more and more interdependent. Hence its development will hasten the formation of these new groups of civilization. Such international federations will not inaugurate an era of cosmopolitanism; they will not suppress nationality, but will rather tend to encourage national individuality. Switzerland today, which includes not one nationality, but a federation of three nationalities, is the prototype. This offers the miniature of one of Novicow's groups of civilization. It is interesting to note that he considers invention, ${ }^{2}$ especially invention leading to increased communication, as the main factor in the process of socialization and assimilation. This will, he declares, in the course of time be responsible for the creation of international federations. Thus he assumes the function of assimilation to be, first, the

${ }^{x}$ CH. Richet, Dans cent ans, p. 79 ; quoted by Novicow, p. 615.

${ }^{2}$ On the subject of invention see Professor Lester F. Ward's Psychic Factors of Civilization, chaps. xxvii, xxviii, and xxix. He says : "It is easy to see .... that this [invention] is the real civilizing agent. If certain refining influences, largely dependent indirectly upon this, be left out of the account, it is correct to say that civilization consists in the utilization of the materials and forces of nature, and the exclusive means by which this is accomplished in human invention." (P. 189.) 
establishment of nationality, and, afterward, the creation of internationality, if the term may be used.

In brief, the function of assimilation is the establishment of homogeneity within the group; but this does not mean that all variation shall be crushed out. In vital national matters, such as language, ideals of government, law, and education, uniformity shall prevail; in personal matters of religion and habits of life, however, individuality shall be allowed free play. Thus the spread of "consciousness of kind" must be accompanied by the spread of consciousness of individuality.

Next, what is the relation of assimilation to political groups? Purposive assimilation begins with the historical state. The political organization of society gives birth to the process of assimilation, which in its turn calls forth in later ages the nation. The state is formed wholly on a material basis; the nation rests on a psychic basis. The controlling power in the state is material interests; the controlling power in the nation is sentiment, affinity, and sympathy. ${ }^{\text {I }}$ Assimilation results in "the modern kinship known as Nationality, which enables us to speak of Englishmen, Frenchmen, Australians, and Americans." ${ }_{2}$ According to Novicow, a nation cannot be better defined than as "a group of individuals alike in their manner of feeling." 3 "A nation means a like body of men, because of that likeness capable of acting together, and because of that likeness inclined to obey similar rules," says Bagehot.4 It is certainly true

that the members of such a group should be similar enough to one another to coöperate easily and readily together. The coöperation in all such cases depends on a felt union of heart and spirit; and this is only felt when there is a great degree of real likeness in mind and feelings, however that likeness may have been attained. 5

In every society we find certain forces at work which antagonize the assimilating process and prevent the spread of

I" In social evolution we progress from community of material interests (state) to the community of ideas, sentiments, and desires (nationality)." (Novicow, Les Luttes entre Sociétés humaines, p. 25I.)

2 Maine, Early Law and Custom, p. 216.

3 Novicow, Les Luttes entre Sociétés humaines, p. 247.

4 Bagehot, Physics and Politics, p. 2 I.

5 Ibid., p. 213. 
sympathy and fellowship feelings. These obstacles may now be summed up briefly thus: (I) lack of a vital circulation in society, owing to the difficulty of intercourse; (2) strong barriers of religion or tradition which prevent interclass assimilation and cause monopoly of civilization by the ruling minority; (3) exclusion of a majority from participation in military and political life; (4) maladministration of justice, which grants political and social privileges to some, and imposes corresponding restrictions on others; this policy tends to accent differences between members of the same group, and thus to foster heterogeneity; (5) predominance of custom over mode imitation; and (6) persistence of group-feeling in the passive element. This is due to: (I) consciousness of belonging to a Culturvolk; (2) a culture so foreign that there is no common meeting-ground; (3) segregation; and (4) persistence of the foreign language.

SARAH E. Simons.

Washington, D. C.

[To be continued.] 